\title{
Proaktywność versus poczucie skuteczności w procesie konstruowania kariery przez młodzież
}

\section{KEYWORDS}

proactivity, professional career, self-efficacy in action, labour market, youth

\begin{abstract}
Myszka-Strychalska Lucyna, Proaktywność versus poczucie skuteczności w procesie konstruowania kariery przez młodzież [Proactivity versus self-efficacy in the process of developing a career by the youth]. Kultura Społeczeństwo - Edukacja nr 1(17) 2020, Poznań 2020, s. 147-162, Adam Mickiewicz University Press. ISSN 2300-0422. DOI 10.14746/kse.2020.17.8.1
\end{abstract}

The contemporary labour market is characterised by broadly understood flexibility which conditions the uncertainty of the professional situation of a person participating therein. One of the factors increasing their chances to have a successful career are not only relevant competences, qualifications and proactive behaviours to the benefit of their own development, but also their trust in their own abilities. In this article it has been attempted to confirm the thesis on the existence of co-dependence between the individual's proactivity and self-efficacy in the process of developing a professional career. To this end, a review of selected theoretical depictions on both, constructs and results of research explorations specifying mutual relations, was conducted. The observations made have both, theoretical and practical implications that are interesting in cognitive terms. The analysis thereof may prove to be especially important with regard to young people who are preparing to enter the labour market.

* ORCID https://orcid.org/0000-0003-2973-1379. 


\section{Wstęp}

W myśl współczesnych koncepcji kariery to człowiekowi przypisuje się coraz większą odpowiedzialność za przebieg rozwoju zawodowego. Uznaje się go bowiem za podmiot planujący i zarządzający własną ścieżką zawodową. W tym kontekście, uzasadnione okazuje się poddawanie wnikliwemu oglądowi konstruktu indywidualnej proaktywności (Griffin, Neal, Parker, 2007). Jednostka podejmująca działanie ukierunkowane na zmianę rzeczywistości zgodnie z perspektywą wyznaczoną przez przyszłe cele, aspiracje i potrzeby zawodowe, przyjmuje na siebie odpowiedzialność za oddziaływanie na proces tej zmiany, korzystając ze zgromadzonych przez siebie zasobów. Osoby proaktywne bywają też określane mianem podejmujących ,inicjatywę personalną" (personal initiative) (Fay, Frese, 2001), „agenta zmian” (Bateman, Crant, 1993), „twórczego indywidualisty”, „innowatora roli” (Schein, 1971) czy też „podmiotów działających niezależnie" (Bańka, 2009). Sformułowania te wskazują na znaczący wpływ człowieka na przebieg kariery, co uwypukla jego podmiotową sprawczość i niezależność w tym obszarze.

Analiza konstruktu proaktywności w odniesieniu do kariery zawodowej pozwala na poszerzenie perspektywy oglądu tej płaszczyzny ludzkiej aktywności o różnorodne czynniki mające dla niej znaczenie, zanim zostaną one w pełni definiowane bądź zmaterializowane. W teorii proaktywnego radzenia sobie człowiek postrzegany jest jako podmiot zdolny do podejmowania decyzji oraz działań w obliczu przewidywanych sytuacji. Kluczowym kryterium do identyfikacji proaktywnych zachowań jest zatem to, czy jednostka przewiduje, planuje i próbuje stworzyć przyszły wynik, który ma wpływ na nią lub środowisko (Grant, Ashford, 2008; Parker i in., 2006).

Konglomerat współczesnych przeobrażeń rynku pracy sprawia, iż proaktywność jednostki niejednokrotnie ma większe znaczenie dla przebiegu ścieżki jej kariery niż wsparcie udzielane młodzieży przez placówki edukacyjne czy też pracodawców zatrudniających nowych pracowników. Właściwość ta przyczynia się bowiem do samodzielnego podejmowania przez nią inicjatyw, które mogą przynieść korzystne rezultaty w przyszłości. Osoby adaptabilne charakteryzują się umiejętnością elastycznego funkcjonowania w rzeczywistości permanentnych przemian, co okazuje się korzystne dla ich kapitału kariery. Nieodzownym czynnikiem warunkującym pomyślny przebieg rozwoju zawodowego w niestabilnym świecie jest poczucie samoskuteczności w karierze, odpowiedzialne za wiarę człowieka w efektywne partycypowanie w przestrzeni rynku pracy. Przyglądanie się tej kategorii okazuje się znaczące $\mathrm{w}$ kontekście radzenia sobie podmiotu z wyzwania- 
mi życia codziennego, w tym również związanymi z osiąganiem satysfakcji zawodowej, sukcesem w karierze czy też spostrzeganiem swojej osoby i kształtowaniem tożsamości.

Zrozumienie zależności pomiędzy proaktywnością jednostki a jej poczuciem skuteczności staje się zatem jednym z istotnych zadań nauk społecznych, w obszarze zainteresowań których plasują się zagadnienia związane z karierą zawodową oraz przygotowaniem młodych ludzi do aktywnego uczestnictwa w rynku pracy. Rozpoznanie tych konstruktów pozwoli „skuteczniej przewidywać to, jak ludzie się zachowają i jaki będzie skutek ich działania poprzez poznanie ich punktu widzenia na temat tego, jak oceniają swoje możliwości” (Bańka, 2004: 204).

\section{Proaktywność w karierze}

W kontekście rozważanej problematyki warto poddać bliższemu oglądowi teorię proaktywnego radzenia sobie, której autorami są niemieccy badacze Ralph Schwarzer i Steffen Taubert (1999). Ujęcie to wzbogaca wiedzę naukową z zakresu analizy procesów poznawczych i zachowania człowieka w sytuacjach trudnych i stresujących. Ze względu na to, iż koncentruje się na rozpoznawaniu czynników wzmacniających osiąganie celów przez jednostkę, jej zaangażowaniu i samodoskonaleniu, może okazać się pomocna przy rozpatrywaniu różnych sytuacji życiowych, w tym również związanych z aktywnością zawodową (zob. Ślebarska, 2017).

Zgodnie z założeniami wspominanej teorii proaktywne radzenie sobie „obejmuje autonomiczne i samodzielne stawianie sobie celów będących wyzwaniem i ich konsekwentną realizację (...) dotyczy samoregulacyjnych procesów osiągania celu i stara się wyjaśnić, co motywuje ludzi do dążenia do ambitnych celów i angażowania się w samodoskonalenie” (Schwarzer, Taubert, 1999: 86). Jej twórcy wyraźnie akcentują, iż należy rozróżniać proaktywne radzenie sobie (proactive coping) od innych typów zachowania, takich jak: reaktywne radzenie sobie (reactive coping), antycypacyjne radzenie sobie (anticipatory coping) czy też prewencyjne radzenie sobie (preventive coping) (Schwarzer, Taubert, 2002). Podejścia reaktywne stosowane są przez jednostkę w sytuacji już zaistniałych wydarzeń i stanowią wypadkową jedynie jej reakcji w przypadku określonych okoliczności (zob. Albion, Fernie, Burton, 2005). W refleksji odnoszącej się do kariery zawodowej, wymagającej planowania oraz mającej dynamiczny i często nieprzewidywalny charakter, perspektywa ta jest niewystarczająca. Dlatego też teoria proaktywnego radzenia sobie przewiduje uwzględnianie w analizach przyszłych wyzwań podejmowanych przez podmiot z jego własnej inicjatywy. 
Osoby proaktywne podejmują działania mające konstruktywne znaczenie dla przyjętej przez nich wizji przyszłości (zazwyczaj w perspektywie długoterminowej). Koncentrują się na gromadzeniu zasobów, które mogą okazać się pomocne w rozwoju osobistym, zaś wszelkie zagrożenia traktują w kategoriach wyzwań. Ludzie proaktywni skupiają się na zarządzaniu wyznaczonymi celami, których realizacja przyczyni się do poprawy jakości ich życia, a także zwiększy ich wydajność. Istotnym procesem poprzedzającym wszelkie działanie jednostki jest ocena poznawcza oraz rozpoznanie motywacji. W związku z tym, iż proaktywne radzenie sobie ma przede wszystkim charakter autoregulacyjny i ukierunkowany jest na osiąganie przyjętych założeń, ważny czynnik warunkujący jego powodzenie stanowi poczucie skuteczności działania (self-efficacy), rozumiane jako optymistyczne przekonanie o tym, iż można inicjować i utrzymywać trudne kierunki działania (Schwarzer, Taubert, 2002).

Schwarzer i Taubert akcentują, iż należy rozróżniać proaktywne zachowanie od proaktywnej postawy, która prezentowanym przez nich ujęciu rozumiana jest jako pewna dyspozycja, wrodzona skłonność człowieka. To właśnie postawa warunkuje proaktywne radzenie sobie, które oddziałuje na kształtowanie osobowości proaktywnej dookreślanej przez takie cechy, jak zaradność, odpowiedzialność, wartość i wizja. Zgodnie z takimi założeniami osoba proaktywna będzie przekonana o istnieniu wewnętrznych oraz zewnętrznych zasobów pozwalających na osiągnięcie przyjętego celu. Przyjmuje ona analityczne podejście do różnorodnych sytuacji, rozpatrując je w kategoriach swoich zobowiązań wobec przeszłych wydarzeń i realizacji zadań. W zdecydowanie większym stopniu koncentruje się na tych, które przyczyniają się do sprostania wyzwaniom w sposób zgodny z własnymi wartościami (Schwarzer, Taubert, 2002).

Warto w tym miejscu zaznaczyć, iż w opracowaniach poświęconych proaktywności pojawiają się analizy prezentujące ją zarówno jako cechę osobowości (Crant, 2000; Frese i in., 1996), jak i jako postawę ukierunkowaną na zmianę zasobów osobistych (Hobfoll, 2006). Augustyn Bańka podkreśla, iż niemożliwe jest całkowite rozróżnienie proaktywności jako cechy osobowości od proaktywności jako postawy zaangażowania, która wywoływana jest przez określone sytuacje i okoliczności (Bańka, 2009: 18). Należy bowiem zauważyć, że przejawianą przez jednostkę formę proaktywności z jednej strony warunkują jej predyspozycje, z drugiej zaś kontekst jej życia i presja środowiskowa. Dlatego też w niektórych ujęciach zachowania proaktywne są przedstawiane jako ciąg powiązanych ze sobą aktów i faz (Grant, Ashford, 2008), inne zaś koncentrują się na analizie wariancji zmiennych wynikowych oddziałujących na sukces zawodowy jednostki.

Wspomniany Augustyn Bańka (2009, 2015, 2016) rozważania na temat proaktywności sytuuje w perspektywie interakcyjnej. Badacz ten definiuje ją jako „intencjo- 
nalne uruchamianie przez jednostkę działania w czasie rzeczywistym bez konkretnej intencji zrealizowania ostatecznego celu tu i teraz" (Bańka, 2015: 98). W niniejszym rozumieniu jej istotą jest przyświecająca człowiekowi chęć wywołania zmiany w otaczającej go rzeczywistości, która ma być pomocna w zachowaniu poczucia tożsamości, zaufania do siebie czy też efektywności podejmowanych przedsięwzięć. Dlatego też ze względu na nieocenioną rolę proaktywności w sytuacjach trudnych oraz towarzyszące jej refleksyjne zaangażowanie podmiotu, Bańka uznaje ją za formę zaradności i adaptacji do warunków nieprzewidywalnego świata (2015: 98).

W tak nakreślonej perspektywie uzasadnione jest analizowanie konstruktu proaktywności w odniesieniu do kariery zawodowej i współczesnego rynku pracy. Obok otwartości i elastyczności jest ona bowiem uznawana za jedną z cech dookreślających dojrzałość do kariery (Bańka, 2009). Proaktywność w tej sferze ludzkiej partycypacji będzie się zatem przejawiała w wysokim stopniu inicjacyjności w podejmowanych aktywnościach zawodowych, wykorzystywaniu nadarzających się szans na odniesienie sukcesu i efektywnym radzeniu sobie z trudnościami. Działania podejmowane przez osoby o wysokim stopniu proaktywności mogą korzystnie oddziaływać na zmiany całej organizacji. Za wyznaczniki proaktywnych zachowań w karierze przyjmuje się realizację celów wyznaczanych przez jednostkę oraz potrzeb związanych z jej osiągnięciami i aspiracjami (Fay, Frese, 2001; Frese, i in., 1997). Ich efektywność warunkowana jest przez ciągłą eksplorację środowiska, która dostarcza jej informacji niezbędnych do podejmowania decyzji i planowania kolejnych działań oraz umożliwia nawiązywanie nowych znajomości i budowanie sieci kontaktów z różnymi osobami tak zwanego networkingu. Proaktywność zwiększa subiektywne poczucie jednostki o odnoszeniu sukcesu w karierze. Prawidłowość ta wynika, z tego, iż osoby dbające o swój własny rozwój zawodowy niejednokrotnie wybierają te środowiska pracy, które charakteryzują się samodzielnością i możliwością samostanowienia, ponieważ ułatwia im to konstruowanie kariery w pożądanym kierunku (Seibert i in., 1999). Ponadto osoby proaktywne przejawiają wyższe zdolności adaptacyjne do nowych miejsc pracy i efektywnie dopasowują je do swoich potrzeb i możliwości (Ślebarska, 2017; Crant, 1995). Można zatem stwierdzić, iż świadomie i odpowiedzialnie monitorują przebieg swojej kariery oraz zarządzają swoim rozwojem.

\section{Poczucie własnej skuteczności w konstruowaniu kariery}

Wprowadzenie pojęcia poczucia własnej skuteczności (perceived self-efficacy) do nauk społecznych przypisywane jest Albertowi Bandurze (1977), który zajmował 
się zagadnieniem modyfikacji ludzkich zachowań. Jego prace wykazały, iż wiara we własne możliwości przyczynia się do większego zaangażowania człowieka w realizowane przedsięwzięcia oraz korzystnie oddziałuje na osiągane przez niego wyniki. Poczucie własnej skuteczności utożsamia się z subiektywnym przekonaniem jednostki, iż jest w stanie podejmować i kontrolować określone działania, innymi słowy jest to jej przeświadczenie o posiadanych kompetencjach, warunkowanych przez różne czynniki osobowe i sytuacyjne.

Definicja samoskuteczności, skonstruowana przez Bańkę, w myśl której jest ona „dokonywaną przez ludzi oceną zaufania do własnych zdolności organizowania i egzekwowania określonego kierunku aktywności, wymagającego realizowania różnego rodzaju działań na określonym poziomie sprawności, efektywności i wydajności" (Bańka, 2006: 82), zwraca uwagę na jeszcze jeden wymiar tego konstruktu. Wskazuje bowiem, iż jednostka wierząca we własne możliwości świadomie podejmuje działania ukierunkowujące je na osiągnięcie znanego sobie celu i decyduje o poziomie zaangażowania w jego realizację. Ma ona nadzieję na to, że przedsięwzięte aktywności pozwolą jej na przezwyciężenie potencjalnych sytuacji trudnych, które mają nastąpić w przyszłości (Maddux, Lewis, 1995).

Albert Bandura wyróżnia cztery źródła informacji warunkujące rozwój poczucia skuteczności u podmiotu, takie jak: doświadczenia związane z realizacją zamierzeń i odnoszeniem sukcesów, obserwowanie efektywności działań innych uczestników życia społecznego (modelowanie, doświadczenie zastępcze), perswazje słowne, czyli otrzymywane od otoczenia zachęty budujące przekonanie o posiadaniu kompetencji pozwalających na pomyślne wieńczenie przedsięwzięć, umiejętność radzenia sobie ze stresem i redukowania napięć emocjonalnych (Bandura, 2015: 87). Jednostka ciesząca się powodzeniem przez dłuższy czas nie traci poczucia skuteczności w sytuacji chwilowych porażek, bowiem mobilizują ją one do podejmowania wytrwałego wysiłku. Prawidłowość ta wynika $\mathrm{z}$ tego, iż siła motywacji i determinacja w wykonywanych czynnościach warunkowana jest przez zaufanie człowieka do siebie, nie zaś przez obiektywne czynniki sytuacyjne. Obserwacja sukcesów innych ludzi pozwala na nabieranie przekonania, że poradzi sobie w podobnych okolicznościach. W ten sposób zdobywa doświadczenie bez bezpośredniego uczestnictwa w nim. Kolejnym bodźcem wzmacniającym poczucie skuteczności podmiotu są informacje zewnętrzne na temat umiejętności, werbalizowane przez jego towarzyszy, które mogą okazać się pomocne w realizacji zadania. Znaczenie ich oddziaływania jest efektywniejsze, jeżeli zostaną one potwierdzone w rzeczywistości. Istotną rolę odgrywają także somatyczne i emocjonalne stany w ocenie własnych zdolności. Pozytywny nastrój oraz odporność na stres wzmacnia dostrzeganie 
w sobie pokładów samoskuteczności, podczas gdy zły humor, ból i męczenie znacząco je osłabiają.

Samoskuteczność w karierze (career self-efficacy) jest rodzajem specyficznej samoskuteczności (Lent, Hackett, 1987; Betz, 1992; Bańka, 2016) związanym z zaufaniem jednostki do siebie w kwestii planowania, monitorowania i zarządzania własną ścieżką rozwoju zawodowego. Okazuje się ona niezwykle istotną właściwością dla młodzieży znajdującej się w okresie podwójnej tranzycji z okresu adolescencji do dorosłości oraz z edukacji na rynek pracy, ponieważ stanowi składową jej kapitału kariery, który nie pozostaje bez znaczenia dla kształtowania satysfakcjonującej przyszłości zawodowej (Turska, 2014). Pozwala ona podmiotowi postrzegać siebie jako osobę zdolną do podejmowania działań i osiągania celów, co motywuje do kontynuacji aktywności zawodowych i realizowania własnych aspiracji (Krauze, 2012). Osoby legitymujące się poczuciem skuteczności wykazują także wyższą satysfakcję z wykonywanej pracy i mają rzeczywiste osiągnięcia zawodowe (Klassen, Chiu, 2010).

Przyglądanie się konstruktowi poczucia samoskuteczności w karierze młodych ludzi ma wartość prognostyczną. W przypadku młodzieży uczącej się oddziałuje na ich zachowania związane z kształtowaniem własnej kariery takie jak wybór uczelni czy osiągnięcia edukacyjne (Lent, Hackett, 1987). Ponadto stopień zaufania jednostki do własnych kompetencji, przejawiany w początkowym okresie pracy zawodowej, pozwala przewidzieć jej awanse i sukcesy osiągane w późniejszym czasie (Cervone, 1997). Kategorię poczucia samoskuteczności w karierze można zatem wykorzystać nie tylko do oceny indywidualnych przekonań o szansach na pomyślne zwieńczenie wyznaczonego zadania, ale także jako miernik efektywności funkcjonowania w środowiskach pracy. W pewnym stopniu szacuje ona przygotowanie jednostki do wejścia na rynek pracy, dojrzałość do kariery zawodowej.

Warto wspomnieć, iż konstruktem uzupełniającym rozważania na temat wzajemnych powiązań pomiędzy samoskutecznością a proaktywnością $\mathrm{w}$ procesie konstruowania kariery zawodowej jest umiejscowienie kontroli. Przekonanie o własnej skuteczności koncentruje się na wierze w możliwość wywołania pewnych działań, zaś proaktywność związana jest z podejmowaniem aktywności ukierunkowanych na wywołanie zmian w środowisku, natomiast umiejscowienie kontroli stanowi przeświadczenie jednostki o tym, że określone starania przyniosą pożądane rezultaty. W kontekście kształtowania własnej kariery zawodowej istotne jest wzmacnianie kontroli wewnętrznej podmiotu, ponieważ warunkuje ona jego świadomość wpływania na przebieg wydarzeń, co skutkuje wyższą oceną szans na osiągnięcie sukcesu w działaniach, samodzielnym podejmowaniem decyzji i posiadaniem ambitnych aspiracji (Drwal, 1995). Ponadto wewnętrze umiejscowienie 
kontroli, towarzyszące silnemu poczuciu samoskuteczności, wzmacnia umiejętności jednostki związane z radzeniem sobie w sytuacji trudnej (Bańka, 2016:10).

Podejmowany dyskurs implikuje dostrzeżenie powiązań proaktywności i poczucie samoskuteczności ( $w$ tabeli 1 zestawiono cechy charakterystyczne dla osób legitymujących się tymi właściwościami). Istotą działań proaktywnych jest intencjonalne kreowanie rzeczywistości. Podmiot ukierunkowany na realizację określonego celu będzie konsekwentnie dążył do jego urzeczywistniania. W tak nakreślonej perspektywie można zauważyć nawiązanie do jego wiary we własne zdolności kontrolowania wydarzeń. Poczucie samoskuteczności oddziałuje na myśli, uczucia, motywację i nastawienie jednostki do zadań, co w konsekwencji warunkuje podejmowane przez nią decyzje i wyznaczane cele. Uznaje się je za czynnik determinujący zmianę zachowań na podstawie oceny sytuacji i skutkuje poszukiwaniem efektywnego sposobu radzenia sobie w nieznanej sytuacji (Maddux, Lewis, 1995). Wszystkie te właściwości są zaś niezwykle istotne w podmiotowym konstruowaniu kariery zawodowej. Poczucie zaufania do siebie stanowi jedną z cech osobowościowych zapobiegających bezdecyzyjności wynikającej z uwarunkowań instytucjonalnych bądź strukturalnych (edukacja, rynek pracy) oddziałujących korzystnie na rozwój proaktywności (Bańka, 2013).

Tabela 1. Cechy osoby proaktywnej i osoby mającej wysokie poczucie własnej skuteczności

\begin{tabular}{|c|c|}
\hline Osoba proaktywna & $\begin{array}{c}\text { Osoba mająca wysokie poczucie własnej } \\
\text { skuteczności }\end{array}$ \\
\hline $\begin{array}{l}\text { - eksploruje środowisko w celu rozpoznania } \\
\text { czynników umożliwiających jej osiągnięcie } \\
\text { przyjętych założeń; } \\
\text { - jej zdolności kształtowania środowiska prze- } \\
\text { wyższają możliwości kształtowania jej zacho- } \\
\text { wań przez środowisko; } \\
\text { - jest zorientowana na zmianę, maksymalizację } \\
\text { własnych osiągnięć, myśli przyszłościowo; } \\
\text { - wymusza na środowisku funkcjonowanie zgod- } \\
\text { ne z jej obecnymi potrzebami, mającymi zna- } \\
\text { czenie dla zdarzeń mających dopiero nastąpić } \\
\text { w przyszłości; } \\
\text { - dokonuje ewaluacji swoich działań i sama } \\
\text { przejawia inicjatywę; } \\
\text { opracowuje nowe sposoby osiągania wyznaczo- } \\
\text { nych celów, dostrzega możliwości; } \\
\text { charakteryzuje się świadomością ryzyka } \\
\text { i odpowiedzialnością („odpowiedzialne zaan- } \\
\text { gażowanie”; Morrison, Phelps; 1999), dlatego } \\
\text { podejmuje różne próby działania (stosuje nie- } \\
\text { standardowe strategie); }\end{array}$ & $\begin{array}{l}\text { - trudne zadania postrzega w kategorii wyzwań, } \\
\text { którym można podołać; } \\
\text { - } \text { angażuje się w podejmowane aktywności; } \\
\text { - stawia sobie ambitne cele i zmierza do ich } \\
\text { - charakacji; } \\
\text { minacji w podejmowanych działaniach; } \\
\text { - jej motywacja do działania w większym stopniu } \\
\text { warunkowana jest przez własne przekonania } \\
\text { niż obiektywne warunki sytuacyjne; } \\
\text { - wiara w to, iż może osiągać wyznaczone cele, } \\
\text { daje jej motywację do kontynowania rozpoczę- } \\
\text { tych przedsięwzięć; } \\
\text { - przyczyn niepowodzeń dopatruje się w swoich } \\
\text { niewystarczających staraniach, posiadanych } \\
\text { informacjach lub zdolnościach (czynnikom } \\
\text { będącym w zasięgu ich kontroli); } \\
\text { - jest przekonana o swoich możliwościach spra- } \\
\text { wowania kontroli w różnych sytuacjach, co } \\
\text { redukuje jej odczuwanie stresu, czy też zmniej- } \\
\text { sza podatność na depresję; }\end{array}$ \\
\hline
\end{tabular}




\begin{tabular}{|c|c|}
\hline $\begin{array}{l}\text { - konsekwentnie trwa przy realizacji swoich pla- } \\
\text { nów, kreując sytuacje, które to umożliwiają; } \\
\text { - stara się przewidywać trudności, które postrze- } \\
\text { ga w kategorii wyzwań i podejmować środki } \\
\text { zaradcze; } \\
\text { - ma autentyczne osiągnięcia; } \\
\text { - swoją postawą często oddziałuje na innych } \\
\text { ludzi, różne procesy i wydarzenia; } \\
\text { - często określana jest mianem: lidera, agenta zmia- } \\
\text { ny, twórczego indywidualisty, innowatora roli. }\end{array}$ & $\begin{array}{l}\text { - ma umiejętność uczenia się nowych rzeczy; } \\
\text { - poczucie samoskuteczności oddziałuje korzyst- } \\
\text { nie na jej sposób myślenia o sobie, samoocenę. }\end{array}$ \\
\hline
\end{tabular}

Źródło: opracowanie własne na podstawie: Bateman, Crant, 1993; Crant, 1995; Fay, Frese, 2001; Bańka, 2016 (proaktywność); Bandura, 1998; Bańka, 2016 (poczucie samoskuteczności)

\section{Egzemplifikacje badawcze - proaktywność w relacji do poczucia skuteczności}

Kategorie osobowości proaktywnej, zachowań proaktywnych, poczucia własnej skuteczności stanowią zmienne obszernie eksplorowane w kontekście rozwoju zawodowego człowieka. Dociekania prowadzone w tym obszarze potwierdzają ich znaczącą wartość predykcyjną odnośnie osiągnięć jednostki w różnych strefach funkcjonowania, w tym także doświadczania sukcesów w karierze. Okazuje się, iż przekonanie o własnych predyspozycjach do realizacji zamierzonych celów poprawia funkcjonowanie zawodowe nauczycieli (Kowalczuk-Walędziak, 2012), jakość współpracy zespołowej (Łukasik, 2013) czy też osiągnięcia edukacyjne oraz adaptabilność zawodową podmiotu (Larose i in., 2006, Klimkowska, 2013). Analizy poświęcone proaktywności dowodzą zaś jej ścisłych związków z informacyjnym stylem tożsamościowym (Cybal-Michalska, 2013). Niniejsza zależność potwierdza posiadanie przez jednostki proaktywne pewnych cech osobowościowych, takich jak: otwartość na nowe doświadczenia, chęć poznawania siebie i otaczającego świata oraz autorefleksja. Osobliwość ich podmiotowej inicjatywy wyraża się w antycypacji i aktywnej kreacji przyszłości, co w przypadku młodzieży ma istotne znaczenie dla kształtowania własnego ja.

Ponadto badania związane z problematyką kariery zawodowej odnoszące się do konstruktu proaktywności oraz przekonania o własnej skuteczności pozwalają na dostrzeżenie wielu zależności pomiędzy zmiennymi o charakterze psychospołecznym. Przykładem są własne eksploracje prowadzone wśród młodzieży z zespołów szkół zawodowych ${ }^{1}$. Domena proaktywności ogólnej, pozwalająca na

${ }^{1}$ Badania były prowadzone w wybranych szkołach zawodowych i technicznych w województwie wielkopolskim i kujawsko-pomorskim w 2015 roku metodą sondażu diagnostycznego. Grupa badawcza liczyła 697 respondentów (Myszka-Strychalska, 2016). 
rozpoznanie podejmowanych przez nich zachowań proaktywnych na rzecz projektowania rozwoju zawodowego, jak i również kształtowania obrazu własnej osoby jako odpornej na niepowodzenia i elastycznej w działaniach, została zmierzona za pomocą Skali Proaktywności w Karierze autorstwa A. Bańki (2016). W kwestionariuszu wykorzystano dziesięć stwierdzeń odnoszących się do tego konstruktu. Z kolei w celu dokonania oceny poziomu samoskuteczności w działaniu posłużono się Skalą Poczucia Skuteczności Marii Urban (2008: 255). Skala ta składa się z sześciu stwierdzeń odnoszących się do pięciu poziomów, na których owa skuteczność może być reprezentowana. Analiza materiału empirycznego wskazała na wprost proporcjonalny wzrost poziomu poczucia samoskuteczności w działaniu $\mathrm{w}$ odniesieniu do wzrostu przejawianego przez badanych poziomu proaktywności ogólnej $(S ; \rho=0,267 ; p \leq 0,001)^{2}$.

Tabela 2. Zależność pomiędzy poziomem proaktywności ogólnej a samoskutecznością w działaniu badanej młodzieży

\begin{tabular}{|c|c|}
\hline $\begin{array}{c}\text { Poziom przejawianej samoskuteczności } \\
\text { w działaniu }\end{array}$ & Proaktywność ogólna* \\
\hline Bardzo niski & 31,6000 \\
\hline Niski & 42,4348 \\
\hline Średni & 43,0659 \\
\hline Wysoki & 47,0892 \\
\hline Bardzo wysoki & 51,3152 \\
\hline
\end{tabular}

Źródło: wyniki badań własnych

*Wartości podawane są w postaci średniej arytmetycznej wyników uzyskiwanych przez respondentów przejawiających dany poziom samoskuteczności w działaniu

Wyniki badań pozwoliły także na wykazanie istotnej statystycznie zależności w przypadku proaktywności ogólnej $\left(\chi^{2}=157,102 ; d f=36 ; p \leq 0,001\right)^{3}$ oraz poczucia samoskuteczności w działaniu $\left(\chi^{2}=83,029 ; d f=24 ; p \leq 0,001\right)$ a oceną szans na odniesienie sukcesu w karierze przez młodzież. Oznacza to, że im wyższy poziom zachowań proaktywnych w karierze, tudzież wiary we własne zdolności sprawcze w podejmowanych przedsięwzięciach przejawia respondent, tym wyżej ocenia

${ }^{2} \mathrm{~W}$ obliczeniach wykorzystano nieparametryczną korelację rangową Spearmana, badającą zależność pomiędzy zmiennymi ( $p$ - wartość podaje czy ta zależność jest statystycznie istotna). Za graniczny poziom istotności statystycznej przyjęto wartość $p \leq 0,05$, jaki powszechnie uznaje się w naukach społecznych. Dodatnia wartość tego współczynnika ukazuje, że wraz ze wzrostem poziomu samoskuteczności w działaniu, wzrasta tendencja do przejawiania zachowań proaktywnych.

${ }^{3}$ Do wykazania tej zależności pomiędzy zmiennymi zastosowano test chi-kwadrat. 
swoje szanse na sukces zawodowy, i odwrotnie - im niższy poziom proaktywności ogólnej oraz poczucia samoskuteczności w działaniu badanych, tym większy odsetek wskazań na kategorię „nie mam żadnych szans” w odniesieniu do perspektyw rozwoju zawodowego.

Otrzymane wyniki badań korespondują z innymi eksploracjami prowadzonymi w tym obszarze. Badania realizowane przez R. Schwarzera i S. Tauberta oraz Esther R. Greenglass (1999) wśród polskich i kanadyjskich respondentów dowodzą, iż proaktywne radzenie sobie jest pozytywnie skorelowane z samooceną i poczuciem skuteczności oraz negatywnie z wypaleniem zawodowym. Dalsze dociekania E.R. Greenglass ujawniły istotny statystycznie związek proaktywnego radzenia sobie i poczucia skuteczności z poczuciem sprawiedliwego traktowania w pracy (Greenglass, 2004: 147). Dodatkowych danych na ten temat dostarczają eksploracje Manfreda Diehla, Angelleni B. Semegon i Ralfa Schwarzera wskazujące, iż obie te zmienne są także powiązane z kontrolowaniem uwagi w dążeniu do celu i odpornością na dystraktory (Diehl i in., 2006). Z kolei eksploracje prowadzone wśród osób aktywnych zawodowo przez Antje Schmitt i jej współpracowników wykazały, iż osoby deklarujące wyższy poziom skuteczności w danym dniu pracy przejawiały też większą skłonność do działań proaktywnych (Schmitt i in., 2017). Niniejsze dane sugerują, iż pracodawcy zmierzający do zwiększenia zawodowej efektywności swoich pracowników powinni podejmować działania ukierunkowane na wzmacnianie ich wiary we własne możliwości. Nie bez znaczenia jest również promowanie zachowań przejawianych przez proaktywnych zatrudnionych, ponieważ zwiększa to ich zaangażowanie w wykonywaną pracę i optymalizuje ich środowiska pracy (Dikkers i in., 2010). Warto podkreślić, iż poziom odczuwanej skuteczności w działaniu determinuje jakość zachowań proaktywnych oraz prorozwojowych w karierze, które zazwyczaj zostają utrwalone w odniesieniu do określonej dziedziny zawodowej, w jakiej jednostka czuje się kompetentna (Betz, 2004).

Interesujących poznawczo spostrzeżeń dokonali Den Hartog i Frank Belschak (2012). Prowadzone przez nich badania wśród pracowników wskazały istotny związek między poczuciem samoskuteczności oraz zachowaniami proaktywnymi a zajmowanym stanowiskiem $\mathrm{w}$ firmie. Osoby zajmujące stanowiska kierownicze pozwalające na autonomiczne działanie, przejawiały zarówno zachowania proaktywne, jak i legitymowały się wysokim stopniem zaufania w stosunku do swoich możliwości realizacji zamierzeń. Natomiast pracownicy ze stanowisk charakteryzujących się niską autonomią co prawda prezentowali zachowania proaktywne, jednak dotyczyło to tylko tych osób, które ujawniały niskie poczucie samoskuteczności. Podobne zależności zauważono w przypadku samooceny i ocen pracowniczych. 
Eksploracje Majelle J. Albion, Lorelle J. Burton, Karen M. Fernie (2005) wśród australijskich osób bezrobotnych pozwoliły na stwierdzenie silnych korelacji między trzema zmiennymi: proaktywnym radzeniem sobie (proactive coping), postawą proaktywną (proactive attitude) oraz poczuciem samoskuteczności (general self-efficacy). Dostarczają one interesujących poznawczo spostrzeżeń dotyczących wieku badanych, który znacząco różnicował udzielane przez nich odpowiedzi. Osoby mające doświadczenie zawodowe częściej przejawiały postawę proaktywną i przekonanie o własnej skuteczności niż młodzież rozpoczynająca karierę zawodową. Oznacza to, iż osoby dorosłe dostrzegają potencjał w różnorodnych zmianach i czują się odpowiedzialne za swój rozwój zawodowy, co przekłada się na ich sposób myślenia o swoich umiejętnościach. Taki sposób percepcji rzadziej przejawiany jest przez ludzi młodych. Spostrzeżenie to ma istotne implikacje praktyczne. Zwraca uwagę na konieczność uwzględniania różnic wiekowych i wynikających $\mathrm{z}$ nich potrzeb podczas organizowania form pomocy dla bezrobotnych. Dla osób dorosłych ważne jest, aby rozpoznali i wykorzystali umiejętności, które zdobyli w czasie doświadczeń zawodowych. Z kolei osobom młodszym warto zapewnić szkolenia w zakresie konkretnych strategii radzenia sobie na rynku pracy, które prawdopodobnie zapewnią im pożądane rezultaty.

Warto wspomnieć jednak, iż istnieją badania poświęcone osobom bezrobotnym, wskazujące, że zdecydowanie istotniejszą rolę w poszukiwaniu pracy odgrywają czynniki zewnętrzne wobec jednostki, takie jak sytuacja ekonomiczna czy wsparcie społeczno-socjalne, niż czynniki psychologiczne, w tym również poczucie skuteczności (Kasprzak, 2000). Dłuższy okres pozostawania bez pracy przyczynia się do nabycia przez człowieka przekonania, iż ma niskie zdolności do znalezienia zatrudnienia. Co ciekawsze, badania podłużne prowadzone przez Mariolę Łagunę wykazały, iż osoby uczestniczące w szkoleniach ukierunkowanych na wzmocnienie ich wiary we własne możliwości co prawda wykazywały się większą wiarą w posiadany potencjał, jednak nie przekładało się to rezultaty w postaci otrzymania pracy (Łaguna, 2005).

\section{Podsumowanie i wnioski}

Proaktywność oraz poczucie samoskuteczności można rozważać jako komponenty postaw, orientacji tudzież cechy osobowości, ukierunkowujące zachowania młodzieży na realizację określonych aspiracji i celów w karierze. Spostrzeżenie to uprawnia do wysnucia konkluzji traktującej o tym, że motywy jednostkowe wynikające $\mathrm{z}$ własnych potrzeb podmiotu będą stanowiły postawę aktywności młodych 
ludzi. Oznacza to zatem, iż związek pomiędzy zaufaniem człowieka do własnej efektywności w osiąganiu zamierzeń a przejawianymi przez niego zachowaniami nie jest odległy. Prowadzenie eksploracji i analiz odnoszących się do poczucia samoskuteczności oraz proaktywności dotyczących młodzieży pozwoli na przewidywanie przebiegu ich rozwoju zawodowego w przyszłości.

Przypatrywanie się konstruktowi proaktywności w kontekście konstruowania kariery zawodowej przez człowieka wzbogaca niniejszy obszar analiz o aspekt pozytywnych dążeń ludzkich, emocji, celów, poszukiwania korzyści i sensu w podejmowanych aktywności, jak i również poczucia skuteczności działania. Przekonanie jednostki o pomyślnym zwieńczeniu podejmowanych przedsięwzięć motywuje ją do oddziaływania na otaczającą rzeczywistość i wyznaczania kolejnych wyzwań, co w konsekwencji wzmacnia jej wiarę w posiadane umiejętności. W przedstawionym ujęciu istotną rolę odgrywają dwa czynniki: cel rozwojowy oraz czas. Koncentracja na realizacji przyjętych zamierzeń pozwala na podejmowanie działań zapobiegających niepowodzeniom. Tak nakreślona perspektywa buduje pomost pomiędzy teoriami proaktywnego radzenia sobie oraz teoriami działania i skutkuje włączaniem teorii proaktywności w poczet nowych teorii działania (Ratajczak, 2012). Spostrzeżenie to niesie ze sobą pewną wskazówkę metodologiczną, traktującą o tym, że we wszelkich badaniach dotyczących kategorii proaktywności i poczucia samoskuteczności należy wskazać określoną domenę behawioralną, w kontekście której będzie dokonywać się ich rozpoznania (Betz, Hackett, 2006).

Warto wzmacniać poczucie skuteczności działania i proaktywności już na etapie edukacji. Wymaga to stwarzania sytuacji pozwalających na rozwój kompetencji personalnych poprzez interakcje ze środowiskiem i innymi ludźmi, podejmowanie działań wynikających z odgrywania różnych ról i konfrontacji z potencjalnymi zagrożeniami (Bańka, 2015: 100). Jest to zadanie trudne, wymagające organizacji niestandardowych szkoleń i sytuacji. Kształtowanie postawy proaktywnej u młodych ludzi oraz wzmacnianie ich poczucia skuteczności działania może przynosić pożądane efekty w kwestii profilaktyki zjawiska bezdecyzyjności kariery (career indecisiveness), które jest ich coraz częstszą reakcją jednostki na nieprzewidywalność współczesności (Bańka, 2014).

Zaniechanie działań ukierunkowanych na wzmacnianie wiary młodzieży we własne umiejętności związane $\mathrm{z}$ kształtowaniem ścieżki rozwoju zawodowego może skutkować obniżeniem ich aspiracji edukacyjno-zawodowych, niepełnym wykorzystywaniem posiadanych zasobów, trudnością w podejmowaniu decyzji czy problemami związanymi z realizowaniem ról społecznych (Krauze, 2012: 124). W zabiegach zmierzających do kształtowania zaufania człowieka w swoją zdolność kontrolowania wydarzeń istotna jest znajomość oddziałujących na ich przebieg 
procesów psychologicznych: poznawczych (sposób percepcji zdarzeń, tworzenie scenariuszy przebiegu sytuacji, wybór strategii działania), motywacyjnych (formułowanie znaczącego dla jednostki celu, oczekiwany wynik), afektywnych (ustosunkowanie do wydarzeń, emocje jako źródło informacji) i selekcji (szacowanie własnych możliwości w odniesieniu do sytuacji) (Bandura, 1993; Łukasik, 2013: 55-58). Nie bez znaczenia będzie zatem doskonalenie u młodzieży kompetencji myślenia analitycznego, pozyskiwania informacji na temat otoczenia i siebie, planowania długodystansowego, rozpoznawania i nazywania własnych przeżyć oraz realnej oceny własnych predyspozycji do podejmowania różnego rodzaju działań.

Proaktywność i poczucie samoskuteczności młodzieży wzmacniają jej odpowiedzialne zaangażowanie $\mathrm{w}$ proces konstruowania kariery. Stanowią czynniki istotnie powiązane z motywacją do działania, która, pobudzając tkwiący w niej potencjał sprawczy, oddziałuje na efektywność wykonywanych zadań, radzenia sobie z nimi czy tworzenia ambitnych planów rozwoju zawodowego. Ich kształtowanie u młodych ludzi stanowi zatem jedno z podstawowych zadań edukacyjnych.

\section{Bibliografia}

Albion M.J., Fernie K.M., Burton L.J. (2005), Individual differences in age and self-efficacy in the unemployed, Australian Journal of Psychology, 57(1), s. 11-19.

Bandura A. (1993), Perceived self-efficacy in cognitive development and functioning, Educational Psychologist, 28(2), s. 117-148.

Bandura A. (1994), Self-efficacy, [w:] V.S. Ramachaudran (red.), Encyclopedia of Human Behavior t. 4, s. 71-81, New York.

Bandura A. (2015), Teoria społecznego uczenia się, Warszawa.

Bańka A. (2006), Poradnictwo transnacjonalne. Cele i metody międzykulturowego doradztwa karier, Warszawa.

Bańka A. (2007), Psychologiczne doradztwo karier, Poznań.

Bańka A. (2009), Proaktywność - inencjonalne konstruowanie przyszłości i uprzedzające osiąganie celów personalnych poprzez doświadczanie codzienności, [w:] H. Wrona-Polańska, W. Czerniawska, L. Wrona (red.), Szkice o ludzkim poznawaniu i odczuwaniu. Kraków.

Bańka A. (2013), Zaufanie do siebie w procesie konsolidacji statusu dorosłości: Konstrukcja i charakterystyka psychometryczna Skali Samoskuteczności w Karierze, Czasopismo Psychologiczne, 19(2), s. 281-301.

Bańka A. (2014), Bezdecyzyjność jako psychospołeczny wzór tranzycji do dorosłości: Konstrukcja Skali Decyzyjności Kariery, Czasopismo Psychologiczne, 20(2), s. 237-246. DOI: 10.14691/ CPPJ.20.2.305.

Bańka A. (2015), Intencjonalne konstruowanie przyszłości i wyprzedzające realizowanie celów: walidacja Skali Proaktywności Ogólnej, Czasopismo Psychologiczne, 21 (1), s. 97-115.

Bańka A. (2016a), Poczucie samoskuteczności. Konstrukcja i struktura czynnikowa Skali Poczucia Samoskuteczności w Karierze Międzynarodowej, Poznań-Warszawa. 
Bańka A. (2016b), Proaktywność a tryby samoregulacji. Podstawy teoretyczne, konstrukcja i analiza czynnikowa Skali Zachowań Proaktywnych w Karierze, Poznań-Warszawa.

Bateman T.S., Crant J.M. (1993), The proactive component of organizational behavior, Journal of Occupational Behavior, 14, s. 103-118.

Betz N.E. (1992), Counseling uses of career self-efficacy theory, Career Development Quarterly, vol. 41 , nr 1, s. 22-26.

Betz N.E. (2004), Contributions of self-efficacy theory to career counseling: a personal perspective, Career Development Quarterly, vol. 52, nr 4, s. 340-353.

Betz N.E., Hackett G. (2006), Career self-efficacy theory: back to the future, Journal of Career Assessment, 14 (1), s. 3-11.

Cervone D. (1997), Social-cognitive mechanisms and personality coherence: self-knowledge, situational beliefs, and cross-situational coherence in perceived self-efficacy, Psychological Science, vol. 8, s. 43-50.

Crant J.M. (1995). The proactive personality scale and objective job performance among real estate agents, Journal of Applied Psychology, 80, s. 532-537.

Crant J.M. (2000), Proactive behavior in organizations, Journal of Management, 26 (3), s. 435-462.

Diehl M., Semegon A.B., Schwarzer R. (2010), Assessing attention control in goal pursuit: A component of dispositional self-regulation, Journal of Personality Assessment, vol. 86, nr 3, s. 306-317.

Dikkers J.S.E., Jansen P. G.W., de Lange A.H., Vinkenburg C.J., Kooij D. (2010), Proactivity, job characteristics, and engagement: a longitudinal study, Career Development International, vol. 15, nr 1, s. 59-77.

Drwal R.L. (1995), Poczucie kontroli jako wymiar osobowości - podstawy teoretyczne, techniki badawcze i wyniki badań, [w:] R.L. Drwal (red.), Adaptacja kwestionariuszy osobowości. Wybrane zagadnienia i techniki, Warszawa, s. 199-227.

Fay D., Frese M. (2001). The concept of personal initiative: An overview of validity studies, Human Performance, 14(1), s. 97-124.

Frese M., Fay D., Hillburger T., Leng K., Tag A. (1997), The concept of personal initiative: Operationalization, reliability and validity in two German samples, Journal of Occupational and Organizational Psychology, 70, s. 139-161.

Frese M., Kring W., Soose A., Zempel J. (1996), Personal initiative at work: Differences between East and West Germany, Academy of Management Journal, 39, s. 37-63.

Grant A.M., Ashford S.J. (2008), The dynamics of proactivity at work, Research in Organizational Behavior, 28, s. 3-34.

Greenglass E.R. (2004), Różnice wynikające z ról płciowych, wsparcie społeczne i radzenie sobie ze stresem, [w:] H. Sęk, R. Cieślak (red.), Wsparcie społeczne, stres i zdrowie, Warszawa.

Greenglass E.R., Schwarzer R., Taubert S. (1999), The Proactive Coping Inventory (PCI): A multidimensional research instrument, http://www.psych.yorku.ca/greenglass/.

Griffin M.A., Neal A., Parker S.K. (2007), A new model of work role performance: Positive behavior in uncertain and interdependent contexts, Academy of Management Journal, 50(2), s. 327-347.

Hartog D.N., Belschak F.D. (2012), When does transformational leadership enhance employee proactive behavior? The role of autonomy and role breadth self-efficacy, Journal of Applied Psychology, 97(1), s. 194-202.

Hobfoll E. (2006), Stres, kultura i społeczność, Gdańsk.

Kasprzak E. (2000), Osobowość młodych bezrobotnych a sukces i porażka na rynku pracy, Czasopismo Psychologiczne, vol. 6, nr 1-2, s. 55-61. 
Klassen R., Chiu M.M. (2010), Effects on teachers' self-efficacy and job satisfaction: Teacher gender, years of experience, and job stress, Journal of Educational Psychology, vol. 102, nr 3, s. 741-756.

Klimkowska K. (2013), Orientacja na sukces zawodowy studentów kończacych studia translatorskie, Lublin.

Kowalczuk-Walędziak M. (2012), Poczucie sprawstwa społecznego pedagogów. Studium teoretyczno-empiryczne, Kraków.

Krauze E. (2012), Poczucie samoskuteczności studentów w karierze (komunikat z badań), Problemy Profesjologii, nr 1, s. 121-134.

Larose S., Ratelle C.F., Guay F., Senécal C., Harvey M. (2006), Trajectories of science self-efficacy beliefs during the college transition and academic and vocational adjustment in science and technology programs, Educational Research and Evaluation, vol. 12, nr 4, s. 373-393.

Lent R.W., Hackett G. (1987), Career self-efficacy: Empirical status and future directions, Journal of Vocational Behavior, vol. 30, nr 3, s. 347-382.

Łaguna M. (2005), Spostrzeganie własnej skuteczności i koncepcja Ja u osób bezrobotnych. Możliwości modyfikacji poprzez działania edukacyjne, Psychologia Rozwojowa, vol. 10, nr 1, s. 69-78.

Łukasik I.M. (2013), Poczucie własnej skuteczności we współpracy z grupa. Eksperyment pedagogiczny w przestrzeni akademickiej, Lublin.

Maddux J.E., Lewis J. (1995), Self-efficacy and adjustment. Basic principles and issues, [w:] J.E. Maddux (red.), Self-efficacy, Adaptation and Adjustment: theory, research and application, New York, s. 37-68.

Morrison E.W., Phelps C.C. (1999), Taking charge at work: Extra role efforts to initiate workplace change, Academy of Management Journal, 42, s. 403-419.

Myszka-Strychalska L. (2016), Orientacje zawodowe młodzieży z zespołów szkół zawodowych, Poznań.

Parker S.K., Williams H.M., Turner N. (2006), Modeling the antecedents of proactive behavior at work, Journal of Applied Psychology, vol. 91, nr 3, s. 636-652.

Ratajczak Z. (2012), Przedsiębiorczość w kontekście ogólnej teorii działania, [w:]: Z. Ratajczak. Przedsiębiorczość. Źródła i uwarunkowania psychologiczne, Warszawa, s. 13-26.

Schein E. (1971), The individual, the organization, and the career: a conceptual scheme, The Journal of Applied Behavioral Science, vol. 7, nr 4, s. 401-426.

Schmitt A., Belschak F.D., Den H., Deanne N. (2017), Feeling vital after a good night's sleep: The interplay of energetic resources and self-efficacy for daily proactivity, Journal of Occupational Health Psychology, vol. 22, nr 4, s. 443-454.

Schwarzer R., Taubert S. (1999), Radzenie sobie ze stresem: wymiary i procesy, Promocja Zdrowia, Nauki Społeczne i Medycyna, nr 17, s. 72-92.

Schwarzer R., Taubert S. (2002), Tenacious goal pursuits and striving toward personal growth: Proactive coping, [w:] E. Frydenberg (red.), Beyond Coping: Meeting Goals, Visions and Challenges, London, s. 19-35.

Seibert S.E., Crant J.M., Kraimer M.L. (1999), Proactive personality and career success, Journal of Applied Psychology, vol. 84, nr 3, s. 416-427.

Ślebarska K. (2017), Droga do pracy. Proaktywne radzenie sobie a poszukiwanie zatrudnienia i adaptacja do nowego miejsca pracy, Katowice.

Turska E. (2014), Kapitał kariery ludzi młodych. Uwarunkowania i konsekwencje, Katowice.

Urban M. (2008), Indywidualizm i kolektywizm w świadomości młodzieży. Studium psychologiczno-polityczne, Warszawa. 